\title{
"More Merciful and Not Less Effective": Eugenics and American Economics in the Progressive Era
}

\author{
Thomas C. Leonard
}

Oliver Wendell Holmes was made a Progressive lion upon his pithy dissent to the U.S. Supreme Court's landmark decision to overturn a New York statute restricting (male) bakers' working hours. "The 14th Amendment," said Holmes famously, "does not enact the Social Statics of Mr. Herbert Spencer."1 Twenty-two years later, in another well-known case, Holmes wrote for the majority, which upheld the constitutionality of a Virginia law proposing involuntary sterilization of persons believed to be mentally retarded-the "feebleminded," in the jargon of the day. "The principle that sustains compulsory vaccination is broad enough to cover cutting the Fallopian tubes," Holmes wrote in Buck v. Bell (1927). "Three generations of imbeciles," Holmes volunteered, "is enough."

How does an opponent of Spencerian Social Darwinism come to endorse coercive sterilization of the unfit? This essay argues that, as a matter of history, there is no contradiction in the views that underwrite the

Correspondence may be address to Thomas C. Leonard, Department of Economics, Fisher Hall, Princeton University, Princeton, NJ 08544; e-mail: tleonard@princeton.edu. I acknowledge with gratitude the constructive criticisms of Malcolm Rutherford, Deirdre McCloskey, David Levy, Sandy Peart, Bob Goldfarb, and seminar participants at the annual meetings of the Eastern Economic Association, and of the History of Economics Society.

1. Lochner v. New York, 198 U.S. 45, 76 (1905) (USSC). As popular as his Lochner dissent was with Progressives, Wendell Holmes was no Progressive. He did not share their political program; he merely believed in a kind of judicial restraint - that "general propositions do not decide concrete cases" (Lochner v. New York, 77). Holmes's Lochner dissent explicitly disavows any economic theory, Progressive or otherwise. On the sources of Holmes's jurisprudence, see Menand 2001.

History of Political Economy 35:4 @ 2003 by Duke University Press. 
two opinions. It is not merely that both statutes proposed to subordinate individual rights to a putatively greater social good. ${ }^{2}$ Progressive thought, it turns out, did not have to travel far when it moved from labor statutes conceived as protecting society from Social Darwinism to eugenic legislation conceived as protecting society from persons deemed biologically unfit. The heart of the Progressive enterprise-to improve society by uplifting the industrial poor-was not the whole of the Progressive enterprise. In fact, in the Progressive Era especially, eugenic treatment of those deemed biologically inferior was promoted as a means to the end of uplifting the industrial poor.

The history of eugenics and the history of American economics remain mostly unacquainted. Historians of eugenics have shown little interest in Progressive-Era political economy. And histories of Progressive-Era American economics routinely fail to even mention eugenics or scientific racism, movements with widespread intellectual and political influence. ${ }^{3}$ This essay, which considers the influence of eugenics on American economics in the Progressive Era, begins an attempt to fill this historical lacuna.

The notion that groups of human beings-especially blacks, Asians, Southern and Eastern Europeans, and mental and physical "defectives"should be seen as innately different and inferior, was not new in the Progressive Era. Race prejudice may be as old as human history. What was new in the Progressive Era was the increasingly systematic use of a biological, deterministic discourse to explain and to remedy, often using racial categories, the root causes of economic problems, especially labor and immigration. Progressive-Era prejudice, having acquired the imprimatur of science, was used to buttress the reformist thought and legislation that was so characteristic of the time. Progressive-Era economists not only appealed to eugenics; they also developed and espoused theories that helped promote eugenics, by offering a newfound scientific respectability for the garden-variety prejudices already deeply rooted in American soil.

2. Said Holmes: "We have seen more than once that the public welfare may call upon the best citizens for their lives. It would be strange if it could not call upon those who already sap the strength of the State for these lesser sacrifices, often not felt to be such by those concerned, in order to prevent our being swamped with incompetence" (Buck v. Bell, 274 U.S. 200, 207 (1927) (USSC)).

3. Important exceptions are Hodgson 1991, to which the present article, especially the racesuicide discussion, is indebted, and Ross 1991. 


\section{Eugenics and Scientific Racism}

Racial science begins with the view that human racial differences are real, significant, scientifically measurable, and heritable. Scientific racism is racial science premised on racial hierarchy—-the idea that different races can be ranked by innate fitness. Racists could differ in their views of the implications of racial hierarchy. Thomas Jefferson, for example, believed that blacks were innately inferior, although he wrote that "whatever be their degree of talent it is no measure of their rights." John R. Commons (1907), in contrast, regarded blacks' immutable inferiority as justifying slavery. In Commons's view, poor Appalachian whites, owing to their racial fitness as Anglo-Saxons, could be educated and thereby assimilated into American life. Poor blacks could not be so uplifted; black inferiority, Commons believed, could be remedied only by interbreeding with superior races (213).

Progressive-Era racial scientists, like their mid-nineteenth-century predecessors, were both imprecise and inconsistent when defining race. Sometimes the term referred to all of humankind - the human race-and sometimes "race" denoted something like its modern sense-a group roughly defined by skin color and geographic ancestral origin. More commonly, "race" meant nationality, especially when distinguishing among Europeans. Progressive-Era usage routinely treated the English, for example, as a race biologically distinct from, say, the Irish or the Swiss or the Poles. 5

Measurement was essential to racial science; measurement offered a tool for determining racial differences and a potential means for ranking the separate races. Before the advent of intelligence testing, which had its origins in the Progressive Era, racial scientists relied upon anthropometric measurement, especially skull measurement, or craniometry. ${ }^{6}$

4. Letter to Henri Grégoire, 25 February 1809. www.loc.gov/exhibits/jefferson/jeffrep.html.

5. Some Progressive-Era racists, like Madison Grant, author of The Passing of the Great Race, went so far as to claim that different races (in the sense of nationality) were distinct biological subspecies of Homo sapiens. Grant's view was extreme even in the heyday of eugenics and scientific racism, but historically quite continuous with mid-nineteenth-century science, an influential faction of which (the polygenists) regarded races as distinct biological species.

6. Scientific racists had been for some years measuring skull volumes to determine brain size, which was thought to be a proxy for intelligence. Samuel Morton, a Philadelphia physician, meticulously measured the cranial volumes of the hundreds of skulls in his famous collection, and after some egregious finagling of already unreliable data, found that Caucasian brains are larger than American Indian brains, which are larger than Negro brains (Morton 1839). For a debunking of Morton, see Gould 1981, 30-72. See also Menand 2001, 102-10. 
William Z. Ripley, an economist trained at MIT (where he was a favorite of Francis Amasa Walker's) and Columbia, and who spent a long career at Harvard studying railroad economics, wrote perhaps the most influential racial taxonomy of the Progressive Era, The Races of Europe (1899). Ripley employed a well-established and easily obtained measure - the cranial index, or ratio of skull width to skull lengthto classify European Caucasians into three distinct races. The Teutonic (northern) race was long-skulled (dolichocephalic), tall in stature, and pale in eyes and skin; the Mediterranean (southern) race was also dolichocephalic but shorter in stature, and dark in eyes and skin; and people of the Alpine (central) race were round-skulled (brachycephalic), stocky, and intermediate in eye and skin color. Ripley's racial categories were not hard and fast-he was not sure what to do with the Jews, and, in later work, he placed the Slavs into a separate racial category.

By the standards of the day, Ripley was more a racial scientist than a scientific racist. His book explained racial differences on the basis of geography and social factors, not just physical attributes like the cranial index and skin color. His imitators were less restrained. Madison Grant's The Passing of the Great Race ([1916] 1921) borrowed Ripley's taxonomy and served up a catalog of ugly stereotypes, finding not merely inferior races, but inferior social classes, inferior religions (Catholicism), and the inferior sex (women). Grant's screed essentially abandons the scientific part of scientific racism, but his book went into four editions, and was a national bestseller widely taught in universities.

Eugenics derives from the Greek for "well born" and describes a movement to improve human heredity by the social control of human breeding, based on the assumption that differences in human intelligence, character, and temperament are largely due to differences in heredity (Paul 2001). The term eugenics first appears in Francis Galton's Inquiries into Human Faculty (1883), although Galton had already published several eugenicist articles which became a book, Hereditary Genius (1869), arguing that human traits are heritable, and manipulable for social ends. Galton, a well-known polymath and cousin of Charles Darwin, defined eugenics as the social program that aims "to replace natural selection by other processes that are more merciful and not less effective." Eugenics' "first object," says Galton $(1908,323)$, "is to check the birth rate of the unfit instead of allowing them to come into being. . . . the second object is the improvement of the race by furthering the 
productivity of the fit by early marriages and the healthful rearing of children." Reducing the children born to the unfit is sometimes called negative eugenics; increasing the children born to the fit is positive eugenics.

Eugenics does not require racism-biological superiority need not be premised on racial hierarchy. In fact, early eugenic research in the United States studied white families thought to have "degenerate" attributescriminality, pauperism, alcoholism, and prostitution were the chief worries. Richard Dugdale's (1877) famous The "Jukes" considers the family history of an Anglo-Saxon clan and, moreover, gives weight to environmental as well as hereditary causes of degeneracy.

During the Progressive Era, however, American eugenic thought became racist. The rise of hereditarian science likely reinforced the trend. German biologist August Weismann's watershed finding in 1889-that mice with their tails cut off do not bear short-tailed progeny-was intended as a refutation of Lamarckism, the idea that parents' acquired characteristics can be inherited by offspring. Weismann's result-which showed only that acquired characteristics are not inherited-was commonly read as a brief for the idea that bad blood would undermine the social improvement of bad homes. The rediscovery in 1900 of Gregor Mendel's work gave eugenicists hope that the laws of human heredity would be discovered and exploited.

American eugenics in the Progressive Era tended to be racist, but the catalog of unfit persons included far more than inferior races. Fitness was also applied to sex and class. Women and the "lower orders," whatever their race, were commonly regarded as biologically inferior. There is, for example, an entire eugenics subgenre dedicated to the worry that upper-crust college men and women are being outbred by their socioeconomic inferiors. Scholars from traditionally black colleges worried about the lower fertility of the Howard University professoriat- " the higher element of the negro race"-when compared with the average African American (Miller 1917).

With so many unfit types to be contended with, it is not surprising that eugenicists found it congenial to treat all human attributes as the product solely of heredity. The research of Charles Davenport, perhaps the leading American eugenicist of the day, provides an example. Davenport, an experienced chicken breeder, collected family pedigrees in The "Jukes" vein. His extensive collection of family records found that albinism, deafness, insanity, epilepsy, alcoholism, manic-depression, 
pauperism, criminality, nomadism, shiftlessness, and thalassophilia run in families, which he read as establishing hereditary cause. ${ }^{7}$

The story of how eugenics came to inform political economy is a complex one. At work are three complementary and reinforcing themes. The first theme is the one just sketched: the rise of scientific racism and other theories of degeneracy as tools for explaining the conditions of groups on the socioeconomic margins of American life.

The second theme is the advent of the regulatory state. The U.S. government created the Federal Reserve, instituted the income tax, applied antitrust law to firms and to labor unions, and restricted immigration, while state governments regulated working conditions, working hours, and minimum wages. Historians increasingly regard the Progressive Era as a vital precursor-in thought and policy - to the American welfare state (Rodgers 1998; Skocpol 1992). The expansion of state power meant that it was now possible to have not only eugenic thought, but also eugenic practice.

The third theme-the professionalization of American social science-helps explain the increased policy influence of academic experts and legislative activists, who were often one and the same. U.S. Progressive-Era economists, in their overlapping roles as academics and as activists, played an important role in the enactment of immigration and labor legislation. What is less well known is that these economists, especially the Progressives among them, made their case for exclusionary laws by joining economic theory to eugenic thought. Progressive-Era reform legislation invidiously excludes whole groups of persons from citizenship or from labor-force participation, on grounds that exclusion would ameliorate the adverse economic effects of permitting biologically inferior groups to work and live in the United States.

\section{Making Darwin Social: Immigration and "Race Suicide"}

In the late 1880s and into the 1890s, when the U.S. frontier "closed," scholars increasingly viewed population growth with alarm. The economists who wrote on immigration, however, did not make a strictly Malthusian case for too many mouths to feed. What worried the economists

7. Thalassophilia-love of the sea-Davenport concluded must be a sex-linked recessive trait, because it was almost always expressed in male naval officers (Kevles 1995, 49). This paragraph is indebted to Kevles 1995, 44-49. 
was not excess population, but the population's changing racial composition. They well understood the difference; "the cry of race suicide has replaced the old fear of overpopulation," said Simon Patten $(1912,64) .8$ The problem, as some Progressive-Era economists saw it, was not that Malthus was at work, but that Darwin was not. Because these economists feared race degradation more than Malthusian conflict, they founded their arguments for immigration restriction on grounds of blood, not numbers.

Fear and dislike of immigrants certainly were not new to the United States. But professional economists-notably Francis Amasa Walker (1891, 1892), Frank Fetter (1899), and Edward A. Ross (1901a)—were among the first to provide scientific respectability for race-based immigration restriction. ${ }^{9}$ Race-based immigration restriction was justified by what came to be called "race suicide." Race suicide joins scientific racism to differential fertility, naming a process whereby a superior native stock is outbred by prolific, inferior immigrant stock.

Progressive-Era economists explained both sides of the differential fertility story. In explaining why poor immigrants were more prolific, they emphasized how economic life under industrial capitalism was increasingly dysgenic, that is, tending to select for the unfit. Simon Patten, for example, emphasized the dysgenic effects of industrial capitalism's higher living standards. Technological advancement and increases in productivity had removed the natural discipline of the survival of the fittest, making it more likely that the unfit would survive to reproduce. "Every improvement which simplifies or lessens manual labor," explained Patten, "increases the amount of the deficiencies which the laboring classes may possess without their being thereby overcome in the struggle for subsistence that the survival of the ignorant brings upon society" (quoted in Ross 1991, 197). Patten here emphasizes not the direct effects of capitalism upon to the poor but its effects upon

8. Frank Fetter's AEA presidential address, for example ("Population or Prosperity") was at pains to characterize his argument against immigration as Malthusian, thus "without race prejudice" and valid whatever the truth of the claim that "present immigration is inferior in racial quality to that of the past" $(1913,13)$. Fetter was being coy; in Fetter 1899 he opposed immigration on race-suicide grounds.

9. See also Mayo-Smith 1888a, 1888b, and 1888c, and Bemis 1888. Mayo-Smith (1888c, 411) said: "It is the right of the higher civilization to make the lower give way before it. It was this right that the nations of Europe felt was their justification in taking possession of this new country. ... The higher civilization has a moral right to triumph over the lower, for it is in this way that the world progresses." 
natural selection: the productivity of capitalism, by making the struggle for existence slightly less desperate, works against natural selection of the fittest. 10

What to do? Patten ultimately argues for the state taking over the task of selecting the fittest-eugenics. "Social progress is a higher law than equality, and a nation must choose it at any cost," said Patten, and the only way to progress is the "eradication of the vicious and inefficient" (199).

Henry Farnam, a Yale economist who cofounded and personally funded the American Association for Labor Legislation (AALL), a leading reform organization, emphasized public assistance as a cause of dysgenic selection:

Every effort ... to remove what Malthus called the "positive checks" to populations, without at the same time increasing the preventative checks, must result in an increase of the very classes which are least able to take care of themselves, and render more and more imperative the solution of that exceedingly difficult problem which Mr. Arnold White calls "sterilization of the unfit." (Farnam 1888, 295)

"We are," worried Farnam, "by means of our very improvements, setting forces in operation which tend to multiply the unfit" (295).

Patten and Farnam see higher living standards and public assistance as less a victory for social justice than as an impediment to Darwinian weeding-out. Their response to what they regarded as the dysgenic effects of industrial capitalism was not to argue (as might a Social Darwinist) against public assistance, but to advocate eugenics, the substitution of social for natural selection of the fittest.

Francis Amasa Walker, the most respected American economist at the beginning of the Progressive Era, and the AEA's first president, offered a "race suicide" account that proved especially influential. Walker's race-suicide theory begins with the lower fertility of the "superior" "native" stock.11 Walker argued that immigration itself checked the natural

10. Patten's influence in Progressive circles derives from his role as a protectionist Wharton School leader who viewed big business as an enemy of society, and, most especially, as an activist who argued that professional economists had an obligation to lead reform movements - to leave the library, write for the newspapers, "and get their inspiration from the struggle ... which passing events reveal" $(1909,9)$. "To be scientific," Patten said, "is to be popular" (8). Students attracted to Philadelphia by Patten's reform activism include many leading Progressive voices, such as Scott Nearing, who later joined the Wharton faculty, and Edward Devine, a social-work professional.

11. Walker uses native to refer to earlier European immigrants of Anglo-Saxon ethnicity. 
fertility of the native population, so that inferior foreign-born stock effectively displaced superior native stock. "The native element failed to maintain its previous rate of increase," says Walker $(1899,423)$, "because the foreigners came in such swarms" (emphasis added).

Why? Walker appealed to the labor problem. "The [native] American shrank from the industrial competition thrust upon him," Walker proposed. "He was unwilling himself to engage with the lowest kind of day labor with these new elements of the population; he was even more unwilling to bring sons and daughters into the world to enter into that competition" (424). Walker $(1896,828)$ characterized the new elements of the population ("immigrants from southern Italy, Hungary, Austria, and Russia") as "beaten men from beaten races; representing the worst failures in the struggle for existence. Centuries are against them, as centuries were on the side of those who formerly came to us."

Racism to one side, Walker's race degeneration theory stood on a shaky inferential foundation. In "Immigration and Degradation," Walker uses early-nineteenth-century population forecasts for 1840 and 1850 , forecasts that effectively assume little immigration. Finding the forecasts quite accurate, but noting ex post the large increase in immigration during the 1830 s and 1840 s, Walker $(1899,422)$ concludes that the unanticipated immigration must have induced a native population decline in fertility, else the forecasts, in assuming little immigration, would have underestimated the total population. Walker's conjecture was not much of a demonstration. It completely fails to consider other likely explanations, for example, that native birthrates declined in response to increased urbanization, higher living standards, and later age of marriage.

More sophisticated analyses, such as R. R. Kuczynski's (1901) comparison of birth rates of foreign-born and native-born populations, had similar problems. Race-suicide advocates read the higher fertility rates of foreign-born mothers (3.1 to 1.6) as conclusive evidence that the inferior immigrant stock was outbreeding the superior natives. (See, for example, economist Walter Wilcox's 1914 article on "differential fecundity" in the Journal of Heredity.) But this reading confuses "nativeborn" with "native stock," since second-generation immigrants (who, born in the United States, are legal citizens) are combined with the Yankee "natives" in the native-born category-so the comparison cannot go to the race-suicide claim. In fact, Miriam King and Steven Ruggles (1990) show convincingly that second-generation immigrants had lower fertility rates than did the Yankee descendants of earlier European 
immigrants, chiefly because of later age of marriage. ${ }^{12}$ Thus was the differential-fertility aspect of the race-suicide claim factually unfounded.

Race-suicide talk was, in any event, typically unburdened with empirical evidence, a point noted by Allyn A. Young (1905, 263). Walker's degeneration-via-displacement theory, although factually unfounded, thus gained a wide currency in academic and policy circles. Walker's scientific reputation - he had directed the U.S. Census of 1870 and 1880if not his science, carried the day. Anti-immigrant groups were pleased to invoke Walker. Henry Pratt Fairchild (1911, 263), an anti-immigrant demagogue at Yale, said, "Our immigrants are not additions to our total population, but supplanters of native children, to whom they deny the privilege of being born." Prescott Hall (1904, 182), cofounder with Robert DeCourcy Ward of the Immigration Restriction League, characterized Walker's race degeneration story thus: "The main point is that the native children are murdered by never being allowed to come into existence, as surely as if put to death in some older invasion of the Huns and Vandals."

The term race suicide is most often attributed to economist-turnedsociologist Edward A. Ross, who said, "The higher race quietly and unmurmuringly eliminates itself rather than endure individually the bitter competition it has failed to ward off by collective action" (1901a, 88).13 Ross was a student of Richard T. Ely's and took politics with Woodrow Wilson. Ross was closely affiliated with another pioneering sociologist, Lester Ward, who had made his reputation by attacking William Graham Sumner, the reform economists' bête noire, whose laissez-faire economics Ely invoked as the chief cause for founding the AEA.

Ross's coinage gained enough currency to be used by a sitting president, Theodore Roosevelt, who called race suicide the "greatest problem of civilization" $(1907,550)$. In that same year, more than forty years after the American Civil War, Ross $(1907,715)$ wrote, "The theory that races are virtually equal in capacity leads to such monumental follies as lining the valleys of the South with the bones of half a million picked whites in order to improve the conditions of four million unpicked blacks."

During his stormy tenure at Stanford, Ross was well known for his stance against Chinese immigration. Speaking before a group of San

12. So, in fact, it was the second generation of the "inferior stock" that accounted for the lower birth rates among the native-born. My discussion is indebted to King and Ruggles 1990.

13. Rexford Tugwell $(1923,201)$ credits his teacher, Simon Patten (without citation), with the coinage. 
Francisco labor leaders, Ross, according to newspaper accounts, said, "Should the worst come to the worst, it would be better for us if we were to turn our guns upon every vessel bringing [Asiatics] to our shores rather than permit them to land" (quoted in Furner 1975, 235-36).

Ross was no outlier. He was a leading public intellectual of his time; his books sold in the hundreds of thousands. Of the many Guilded-Age academic freedom cases, Ross's was the one that galvanized fellow academics, not least members of the American Economic Association. It is no small irony that a vigorous opponent of political and economic freedom should today be so closely associated with the cause of academic freedom.

Ross also popularized the term social control, which became a catch phrase of Progressive-Era reformers, as it was for their successors, the institutionalists. Many took "social control" to refer narrowly to state intervention in the economy. But Ross was not referring to regulatory policy per se. Ross (1901b) employed the term in a broader, sociological sense, to describe the various ways in which society makes individuals conform to social ends.

Ross (1901b) conceives of society organically-as prior to the individual — and by society he means natives of Anglo-Saxon (a.k.a. Aryan) stock. Ross emphasized not the consequences of industrial capitalism per se, but rather the consequences of inferior races_- "Latins, Slavs, Asiatics, and Hebrews"- outbreeding the superior Anglo-Saxon race.

Walker had native-stock mothers reducing births for fear of their offspring being outcompeted by inferior immigrants. Ross's theory was that native Anglo-Saxons, although biologically well adapted to rural gemeinschaft life, were less well suited to modern conditions, the crowded, urban, industrial geselleschaft life. New immigrant stock, while racially inferior, was better adapted to industrial capitalism.

Like Walker, Ross proposes that persons of "inferior" stock outcompete their biological betters, which turns Darwinism on its head. Darwinism defines fitness as reproductive success, so that those who outcompete their rivals in reproductive success are, by definition, fitter. Ross, like others before him, did not regard his paradoxical conclusion as threatening his racist premises. Instead, Ross takes his conclusion as evidence that modern society has become dysgenic. Natural selection is no longer working in the society, just as competition is no longer working in the economy, so the state is needed to regulate human reproduction, just as it is needed to regulate industry. 
Chicago sociologist Charles Henderson chaired the National Conference of Charities and Corrections - a title that, by itself, nicely captures the tension in the Progressive view of economically marginal groups. Henderson (1900, 253), an AALL stalwart, offered banishment to rural labor colonies for the "feebleminded and degenerate" who "are not very numerous, and can all be easily segregated in self-supporting rural colonies." But even segregation was not dire enough for the "obviously unfit." "[The] insane, [the] feebleminded, and epileptics" must, in the name of the greater good, be coercively sterilized:

It is clearly and distinctly the right of a commonwealth, when called upon to support a large number of the obviously unfit, to deprive them of liberty and so prevent their propagation of defects and thus the perpetuation of their misery in their offspring. ... Therefore the policy of painless asexualization is offered. (Henderson 1909, 228-29)

Henderson also harkens to Walker's account in emphasizing racial fitness, not numbers, and in justifying eugenic policy by instancing its putative economic benefits. "This is not an argument against immigration," says Henderson $(1909,232)$, "but only against the immigration of persons who can never be induced to demand a civilized scale of life." And, says Henderson $(1900,253)$, when "[the feebleminded and degenerates] are removed, the real workers will more easily rise in earning power."

The economists' race-suicide argument made new and influential intellectual connections. Walker connected perceived fertility trends to immigration and the "labor problem." The use of socioeconomic position and nationality as proxies for heritable fitness was vital in connecting all of these issues to the eugenics movement. Irving Fisher understood the political advantages of selling eugenics to those already predisposed to racial immigration restrictions. In a 1912 letter to Charles Davenport, Fisher wrote, "Eugenics can never amount to anything practically until it has begun, as Galton wanted it, to be a popular movement with a certain amount of religious flavor in it, and as ... there is already a sentiment in favor of restricting immigration ... this is a golden opportunity to get people in general to talk eugenics" (quoted in Haller 1984, 144).

In making these connections, and in founding exclusionary regulation upon racist eugenics, the race-suicide theorists served as precursors to the Progressive economists affiliated with the AALL. Their AALL successors, who influenced the U.S. reform movement of the latter half of the Progressive Era, would likewise invoke eugenics to defend reform 
legislation, notably legal minimum wages, the sine qua non of labor reform.

\section{Sifting the Industrial Residuum: Legal Minimum Wages as Eugenic Policy}

Disciplinary opposition to legal minimum wages boasts a pedigree of more than 150 years (Leonard 2000). All along the way, however, there have been dissenters, perhaps no more so than in the Progressive Era. Leading supporters of legal minimum wages, certainly the most influential economists among them-Ely, Commons, Henry Rogers Seager, Sidney Webb, John B. Andrews, and others-were Progressive reformers, and many were AALL leaders. Progressive-Era marginalists-Alfred Marshall, John Bates Clark, Frank Taussig, Philip Wicksteed, and A. C. Pigou—generally opposed minimum wages (Leonard 2003b).

More surprising than Progressive support for legal minimum wages was the fact that Progressive economists, like their marginalist interlocutors, believed that binding minimum wages would result in job losses. What distinguished supporters of minimum wages from their marginalist opponents was how they regarded minimum-wage-induced job loss. Whereas the marginalists saw disemployment as the principal cost of binding minima, indeed as the reason to oppose minimum-wage legislation, minimum-wage advocates regarded minimum-wage-induced disemployment as a social benefit-a eugenic virtue of legal minimum wages. Sidney and Beatrice Webb ([1897] 1920, 785) state it plainly: "With regard to certain sections of the population ["unemployables"], this unemployment is not a mark of social disease, but actually of social health."

When Ross $(1936,70)$ said that "the Coolie cannot outdo the American, but he can underlive him," he was making an economic argument. Native workers have higher productivity, claims Ross, but because Chinese immigrants will work for lower wages_-"underliving"-they displace the native workers. Ross does not say why ostensibly moreproductive native workers cannot command relatively higher wages. Progressive-Era labor economics is eclectic on the relation between wages and productivity.

It often posited that the wage for all workers, regardless of their skill, is relentlessly pulled downward by the marginal productivity of the least productive worker - the so-called marginal man-a process sometimes 
known as destructive competition. The immigrant or the woman or the "defective" accepts a low wage and thereby ensures that his or her inframarginal betters get paid less than they deserve. The problem is not that workers are paid a wage less than the value of their marginal products, the sort of exploitation that the marginalists emphasized, but that workers deemed unworthy undercut their more deserving betters.

The idea that inframarginal workers are exploited-paid less than the value of what they produce—dates to von Thünen ([1850] 1966) at least. What was new was the use of scientific racism to vilify the marginal man. Why vilify the most desperate of the industrial poor? Part of the answer is that Progressive wage theories regarded the marginal man as a cause of low wages not merely for himself, but for more-skilled workers as well.

A minority of the working poor, the "industrial residuum," as the Fabians called it, were regarded not as victims deserving public aid, but as threats needing public restraint. This crude eugenic sorting of the industrial poor into worthy and unworthy categories was reinforced by economic theories of wage determination.

Progressive-Era marginalists, such as John Bates Clark, argued, as does modern neoclassical economics, that inframarginal workers (in competitive markets) are not exploited. The inframarginal workers are more productive, Clark argues, because they work with more capital. Diminishing marginal labor productivity, for a class of homogeneous workers, arises from diminishing capital per worker, and not from the innately lower skill of workers hired later (Clark 1899, 321 n. 1). Workers of different skill levels - non-homogenous workers—should thus be regarded as participating in different labor markets. The lower marginal product of the marginal man comes not from biological inferiority, but from relatively less capital with which to work. ${ }^{14}$

In the marginalist scheme, moreover, marginal productivity (assuming an elastic labor supply) determines the wage, and the wage determines the standard of living. Progressive wage theories often reversed the causality. The standard of living determines the wage; workers with lower standards of living are willing to accept lower wages. Why would some classes of workers willingly accept lower wages? Ignorance, worker immobility, and inability to organize are all cited, but an answer was

14. Sympathetic to Progressive causes, and writing well before neoclassical economics develops a monopsony-based explanation, Clark himself is somewhat unclear on the process by which wages may fall below workers' marginal products. See Leonard 2003a. 
sometimes found in race. Low-wage "races" are depicted as innately disposed to endure a low standard of living. Racial theories were flexible enough to found a willingness to accept low wages on racial causes that ran from laziness to greed. 15

Jews were a favorite target. In Races and Immigrants, John R. Commons $(1907,148)$ volunteers that "the Jewish sweat-shop is the tragic penalty paid by that ambitious race." Like Ross's coolie, Commons's Jew is industrious but less productive than native workers. The tragedy Commons refers to is the process by which ambition leads to destructive wage competition. Wage competition destroys not only wages; it also, for Commons, is biologically destructive-dysgenic. "But competition has no respect for superior races," says Commons $(1907,151)$ in an echo of the race-suicide theorists; "the race with lowest necessities displaces others."

The Progressive muckraker Jacob Riis, a protege of Theodore Roosevelt's and generally regarded as sympathetic to the urban working class, whose conditions he documented in his sensational book, How the Other Half Lives, provides another example. Riis ([1890] 1997) casually averts to racial causes when explaining the low wages of tenement New York. In chapters titled "Jewtown" and "The Sweaters of Jewtown," Riis argues that Jewish sweatshop bosses, although themselves once sweatshop workers, readily exploit new workers, because Jews are incorrigibly greedy.

Riis explains New York's cheap clothing as the product of "the cutter's long knife [a technological innovation] and the Polish Jew," where the latter has "cut deepest into the workman's wages" (92). "The Jew has monopolized the [garment] business," Riis avers, but "not satisfied with having won the field, he strives as hotly with his own [fellow Jews] for the profit of half a cent as he fought with his Christian competitor for the dollar" (92).

Riis explains wage determination as did Commons - using crude racial stereotypes. Jews accept low wages because they accept a low standard of living, and Jews accept a low standard of living because they are

15. John R. Commons $(1907,136)$ volunteered that blacks' putative willingness to accept low pay comes from their innate laziness- "in the entire circuit of the globe those races which have developed under a tropical sun are found too indolent and fickle." Innate indolence and fickleness explain why, Commons argues, slavery was required: "The negro could not possibly have found a place in American industry had he come as a free man. ... if such races are to adopt that industrious life which is a second nature to races of the temperate zones, it is only through some form of compulsion" (136). 
thrifty and love money. "[The Jew's] price is not what he can get," says Riis, "but the lowest he can live for and underbid his neighbor" (92).

"Thrift is the watchword of Jewtown, as of its people the world over," says Riis. Thrift is Jewtown's "cardinal virtue and its foul disgrace," for thrift "has enslaved [Jews] in bondage worse than that from which they fled" (83). Because, Riis explains, "money is their God," life for Jews is "of little value compared with even the leanest bank account" (83).

The example of Columbia's Henry Rogers Seager, a leading Progressive economist, is also instructive. ${ }^{16}$ In some places, Seager argues for higher minimum wages on eugenic grounds. In later editions of his successful textbook, for example, Seager (1923, 615-16) endorses a binding minimum wage. Worthy wage earners, says Seager (1913a, 12), need protection from the "wearing competition of the casual worker and the drifter," as well as from other "unemployables" who unfairly drag down the wages of more deserving higher productivity workers (1913b, 8283). Says Seager (1913a, 9): "The operation of a minimum wage requirement would merely extend the definition of defectives to embrace all individuals, who even after having received special training, remain incapable of adequate self-support." 17

So, which workers are deemed unemployable? Seager thought of "unemployables" as workers whose marginal product is worth less than a "living wage," by which he means income to meet all expenses of a worker living independently. But the imprecision of the term living wagewhat is a decent standard of living, and should a living wage support a family as well, and, if so, a family of what size-opened the door to a flexible interpretation of who deserved work. The Webbs ([1897] 1920, 785), for instance, classified as unemployable

children, the aged, and the child-bearing women ... the sick and the crippled, the idiots and lunatics, the epileptic, the blind and the deaf and dumb, the criminals and the incorrigibly idle, and all those who are actually "morally deficient" ... and [those] incapable of steady or continuous application, or who are so deficient in strength, speed or

16. The remaining discussion in this section borrows from Leonard 2003a, 527-29.

17. Said Seager: "One important part of the program with reference to those who are defective from birth is to prevent that monstrous crime against future generations involved in permitting them to become the fathers and mothers who must suffer under the same handicap. If we are to maintain a race that is to be made up of capable, efficient and independent individuals and family groups we must courageously cut off lines of heredity that have been proved to be undesirable by isolation or sterilization" $(1913 \mathrm{a}, 10)$. 
skill that they are incapable ... of producing their maintenance at any occupation whatsoever.

"Of all ways of dealing with these unfortunate parasites," Sidney Webb $(1912,992)$ argues, "the most ruinous to the community is to allow them unrestrainedly to compete as wage earners."

Seager and Webb, leading Progressive economists, were not anomalous. Royal Meeker, a Princeton Progressive who served as the third U.S. commissioner of labor, rejects subsidizing the wages of poor workers in favor of the disemployment a minimum wage would induce-an efficient means of culling out the least productive workers.

It is much better to enact a minimum-wage law even if it deprives these unfortunates of work. Better that the state should support the inefficient wholly and prevent the multiplication of the breed than subsidize incompetence and unthrift, enabling them to bring forth more of their kind. (Meeker 1910, 544)

Sidney Ball, an Oxford Fabian, also promotes the eugenic virtues of minimum wages. For Ball, the disemployment from a legal minimum wage demarcates the unfit, something that dysgenic markets cannot do:

The Socialist policy, so far from favoring the weak, favors the strong. ... it is a process of conscious social selection by which the industrial residuum is naturally sifted and made manageable for some kind of restorative, disciplinary, or, it may be, surgical treatment. (Ball 1896, 295)

A. B. Wolfe, an American reformer, also argues for the eugenic virtues of disemployment. "If the inefficient entrepreneurs would be eliminated [by minimum wages] so would the ineffective workers," says Wolfe (1917, 278). "I am not disposed to waste much sympathy with either class. The elimination of the inefficient is in line with our traditional emphasis on free competition, and also with the spirit and trend of modern social economics. ... [These incompetents] are a burden upon society."

Paul Kellogg, editor of the Survey, one of the most influential organs of Progressive ideas, proposes legislation that would deny new immigrants industrial employment by the use of a high legal minimum wage, instead quarantining them in open farming country and villages:

No corporation would hire Angelo Lucca and Alexis Spivak for $\$ 3$ [per day] as long as they could get John Smith and Michael Murphy 
and Carl Sneider for less. It would be the intent and result of such legislation to exclude Lucca and Spivak and other "greeners" from our congregate industries, which beckon to them now. (Kellogg 1913, 75)

Minimum-wage-era Progressives, like their immigration-restriction antecedents in Walker and Ross, used the law to invidiously exclude whole classes of persons from the labor force, and regarded such exclusion as socially beneficial. And, as with Walker and Ross, the economic basis for exclusion - what made one an unemployable-was explained by a putative biological inferiority.

Not all minimum-wage proponents proposed the most drastic measures-sterilization or segregation - for those who lost their jobs to minimum wages. Some, like Seager, also proposed, at least for some groups, more humane policies, which ranged from public assistance, to public employment, to training and schooling. But most economists defending exclusionary legislation seem to have believed that some groups were so biologically disadvantaged, and so socially dangerous, as to require drastic measures. John R. Commons (1897) estimated that "defectives" constituted fully 5.5 percent of the U.S. population in 1890, and that nearly 2 percent of the population was defective by heredity, thus irredeemable, and candidates for segregation. Commons's estimates do not include other groups he regards as beyond public help, such as African Americans.

It is a Whiggish temptation to regard Progressive thought of a century ago as akin to contemporary progressivism. But Progressive-Era Progressives viewed the industrial poor with great ambivalence. Their goal to uplift the industrial poor was entangled with a view that uplift of the worthy poor required social control of the unworthy poor. ProgressiveEra Progressives believed that the industrial poor should be protected from the depredations of industrial capitalist society, but they also believed that society should be protected from the depredations of the industrial poor.

The obvious tension in this view was released by theoretically separating the industrial poor into worthy and unworthy categories. Biological fitness determines who is worthy and thereby entitled to social justice, and who is unworthy, and thereby entitled to social control. Groups deemed eugenically unfit-immigrants, blacks, those defective in character and intellect - are treated not as victims, but as threats to the health and well-being of the worthy poor and of society at large. 


\section{Social Justice and Social Control}

What explains the apparent fact that, in American Progressive-Era economics, Progressive reformers are disproportionately represented among economists influenced by eugenics? ${ }^{18}$ It is surely not that Progressives were more likely to hold racist beliefs. The pervasiveness of ProgressiveEra prejudice is remarkable, and economists of quite different politics can be found promoting racist views, in the context of eugenics and elsewhere. Writing at the height of Jim Crow, Commons (1907, 3-4) said, "It is now nearly forty years since these opportunities and educational advantages were given to the negro, not only on equal terms, but actually on terms of preference over the whites, and the fearful collapse of the experiment is recognized even by its partisans as something that was inevitable in the nature of the race at the stage of its development."

The American Economic Association published in 1896 a 300-page article "Race Traits and Tendencies of the American Negro" by Frederick Hoffman, an insurance company statistician. Hoffman's offering was virtuoso scientific racism. "The presence of the colored population is a serious hindrance to the economic progress of the white race," said Hoffman (1896, 328-29), and, as such, the "white population ... will not hesitate to make war upon those races who prove themselves useless factors in the progress of mankind." Hoffman says of the alleged decline of black America, which he predicts must continue, "all the facts prove that a low standard of sexual morality is the main and underlying cause of the low and anti-social condition of the race at the present time" (329).

Frank W. Taussig, no reformer but a sometime member of the AALL, endorses, in spectacularly intemperate language, eugenic sterilization of the unfit (Taussig 1921, 332-33). The American Marxist Scott Nearing, who was removed from the Wharton School faculty for his views against child labor in coal mines, published in 1912 a Superman screed that

18. A useful if inevitably imperfect proxy for defining a Progressive economist is affiliation with the American Association for Labor Legislation, founded in 1905, and which Ann Orloff and Theda Skocpol $(1984,726)$ call the "leading association of U.S. social reform advocates in the Progressive Era." Few important Progressive economists did not have ties to the AALL. Richard T. Ely was the AALL's first president, his protégé John R. Commons the first executive secretary. The latter position was soon taken over by Commons's own protégé John B. Andrews, who led the organization for many years. Irene Osgood (who became Irene Osgood Andrews), another Commons disciple, served as the AALL's assistant secretary. Henry Rogers Seager, of Columbia, served as its third and fifth president (Commons was the second to hold the AALL presidency). Charles Richmond Henderson, Chicago sociologist and Social Gospeler, was another AALL leader. See Moss 1996, Skocpol 1992, and Leonard 2003a, 549-51. 
is a virtual museum piece of the brief Nietzschean vogue in eugenicist thought. Charlotte Perkins Gilman, perhaps the most eminent woman economist of the day, produced several articles with racist, eugenicist, and anti-Semitic sentiments. The restless Irving Fisher served as president of the leading U.S. eugenics society (1921), and opposed the First World War on grounds it was dysgenic: "War's real tragedy lies not in wrecked cathedrals, filled graves, or gutted treasure boxes," Fisher explained, but in "its waste of the germ plasm" (quoted in Haller 1984, 88). (On Fisher's eugenics, see Cot 1989.)

What drew Progressives to eugenics was the same set of intellectual commitments that drew them to the AALL. The Progressive intellectual commitments were (1) a belief in the power of scientific social inquiry; (2) a belief in the legitimacy of social control, which derives from a conception of society as an organism prior to and more important than its constituent individuals; and (3) a belief in the efficacy of social control via state scientific management, in particular faith in the ability of academic experts to suspend their own interests and to circumvent (or better, transcend) the messy business of everyday interest-group politics. As one widely read eugenics text put it, "Government and social control are in the hands of expert politicians who have power, instead of expert technologists who have wisdom. There should be technologists in control of every field of human need and desire" (Albert Wiggam's New Decalogue [1923], cited in Ludmerer 1972, 16-17).

This last Progressive belief-that modern conditions of industrial capitalism no longer permitted a quaint liberal individualism, but demanded wise government by expert elites-we can call technocratic paternalism. ${ }^{19}$ The idea is that benignly motivated experts should interpose themselves, in the name of the greater good, to better represent the interests of the industrial poor, for whom many reformers felt contempt as much as pity. ${ }^{20}$

Economists more skeptical of eugenic laws, such as Pigou (1907), were probably no better disposed toward immigrants, the feebleminded, or other allegedly inferior persons, but they were more skeptical about the reliability of eugenic science, and about the likelihood that eugenic

19. The pioneering sociologist Lester Ward called it "sociocracy" - the "scientific control of the social forces by the collective mind of society" (quoted in Fine 1956, 263).

20. Several historians of the Progressive Era find a similar strain of elitism in Progressive thought. See, for example, Rodgers 1982. 
programs would be carried out wisely by governments..$^{21} \mathrm{G}$. K. Chesterton, whose famous opposition to eugenics is usually attributed to his Catholicism, also connected eugenics to Prussianism, says Daniel Kevles, objecting to, in Chesterton's words, the "same stuffy science, the same bullying bureaucracy and the same terrorism by tenth-rate professors that have led the German empire to its recent conspicuous triumphs" (Kevles 1995, 120).

An additional benefit of explaining Progressive enthusiasm for eugenics by reference to a greater enthusiasm for science, social control, and technocratic paternalism is that we avoid a common mistake, conflating Social Darwinism and selectionist thought more generally. Progressives certainly opposed Social Darwinism (a.k.a. conservative Darwinism). But Progressives did not reject "survival of the fittest" ideology. What distinguished the reform Darwinism of Progressives from Social Darwinism is the Progressive belief that the state, as guided by expert science, could do better than "nature" in the essential Darwinian task of weeding out the unfit. 22

Lester Ward provides an illustration. Ward, a Progressive-Era reformer and eugenicist, made his career by attacking Social Darwinism. The state of the human race is "deplorable," argues Ward, but science enables the state to do what nature no longer can. "Are we to accept that modern scientific fatalism known as laissez faire?" asks Ward. No. Since "the end and aim of the eugenists cannot be reproached," Ward (1913, 746-47) concludes, "it is therefore a question of method rather than of principle."

One hundred years ago, eugenic practice entailed state management of human reproduction. A consistent Social Darwinian should prefer the "natural" selection offered by unfettered social competition to the "artificial" selection of the fittest by the state. Sidney Webb, an enthusiastic eugenicist, understood this: "No consistent eugenicist can be a 'Laisser Faire' individualist unless he throws up the game in despair. He must interfere, interfere, interfere!" (Webb 1910-11, 237). Havelock Ellis could argue in 1911 that eugenics was "the only method by which Socialism

21. No group as heterogeneous and fractious as the Progressives could be unanimous behind any issue, eugenics included. Father John Ryan, for example, an influential and stalwart advocate of minimum wages and other labor legislation, opposed sterilization of the unfit on slippery-slope grounds.

22. Today we associate the term Social Darwinism with a quasi-biological defense of the late-nineteenth-century social order-emergent industrial capitalism and a limited state role in the economy - that invokes natural selection and the survival of the fittest to explain and often to justify that social order. 
can be enabled to continue on its present path" (quoted in Freeden 1979, 668). ${ }^{23}$

American economists who might be regarded as reform Darwinians likewise insisted that modern conditions required the state to assume control of human reproduction. Just as labor and goods markets could no longer be left unregulated, so too must the state take over from "nature" the project of selecting the fittest human beings. Irving Fisher $(1907,20)$ captured this expansive view of social control when he said:

The world consists of two classes - the educated and the ignorantand it is essential for progress that the former should be allowed to dominate the latter. ... once we admit that it is proper for the instructed classes to give tuition to the uninstructed, we begin to see an almost boundless vista for possible human betterment.

Race-building via scientific state management of the "germ plasm" was not regarded as fundamentally different in kind from other policies designed to protect society from dysgenic modern forces.

\section{Coda}

Gunnar Myrdal wrote in An American Dilemma (1944), his influential study of race relations, "A handful of social and biological scientists over the last 50 years have gradually forced informed people to give up some of the more blatant of our biological errors. But there still must be other countless errors of the same sort that no living man can yet detect, because of the fog within which our type of Western culture envelops us" (quoted in Gould 1981, 23). In The Mismeasure of Man, Stephen Jay Gould invokes Myrdal's passage as a commentary on the real difficulties that arise when trying to disentangle the effects of culture on science from the effects of science on culture.

Gould was perhaps unaware that Myrdal knew whereof he spoke. Both Myrdal and his wife Alva were themselves eugenicists who promoted an expansion of Swedish coercive sterilization laws during World War II. More than 60,000 Swedes, over 90 percent of them women, were sterilized from 1941 to 1975 (Broberg and Tydén 1996, 109-10). The Myrdals' eugenics was not racist. They saw forced sterilization of the

23. I am here indebted to Diane Paul's (1984) pioneering paper on left eugenics, for quotations and for insight. 
unfit, says Daniel Kevles $(1999,437)$, "as part of the scientifically oriented planning of the new welfare state." Said Alva Myrdal in 1941: "In our day of highly accelerated social reforms the need for sterilization on social grounds gains new momentum.... The fact that community aid is accompanied by increased fertility in some groups hereditarily defective or in other respects deficient and also the fact that infant mortality among the deficient is decreasing demands some corresponding corrective" (quoted in Broberg and Tydén 1996, 105).

Gunnar Myrdal's meta-scientific insight was correct: scientists cannot step wholly outside the culture in which they perform their scientific work. But Myrdal was unable or unwilling to apply this insight to his own scientific advocacy of eugenics. Instead, a rival and ultimately more powerful Progressive idea carried the day; at the end of An American Dilemma, Myrdal (1944, 1024) writes: "We have today in social science a greater trust in the improvability of man and society than we have ever had since the Enlightenment."

\section{References}

Ball, Sidney. 1896. The Moral Aspects of Socialism. International Journal of Ethics 6.3:290-322.

Bemis, Edward W. 1888. Restriction of Immigration. Andover Review 9 (March): 251-64.

Broberg, Gunnar, and Mattias Tydén. 1996. Eugenics in Sweden: Efficient Care. In Eugenics and the Welfare State, edited by Gunnar Broberg and Nils Roll-Hansen, 77-149. East Lansing: Michigan State University Press.

Clark, John Bates. 1899. The Distribution of Wealth: A Theory of Wages, Interest, and Profits. New York: Macmillan.

Commons, John R. 1897. Natural Selection, Social Selection, and Heredity. Arena 18:90-97.

ـ 1907. Races and Immigrants in America. New York: Chautauqua Press.

Cot, Annie L. 1989. Le gène et l'intérêt: L'anamorphose d'Irving Fisher. Économies et sociétés 23.6:89-107.

Dugdale, Richard. 1877. The "Jukes": A Study in Crime, Pauperism, Disease, and Heredity. New York: G.P. Putnam's Sons.

Fairchild, Henry Pratt. 1911. The Paradox of Immigration. American Journal of Sociology 17.2:254-67.

Farnam, Henry W. 1888. The State and the Poor. Political Science Quarterly 3.2:282-310.

Fetter, Frank A. 1899. Social Progress and Race Degeneration. Forum 28 (October): 228-38. 
1913. Population or Prosperity. American Economic Review 3.1 (supplement): 5-19.

Fine, Sidney. 1956. Laissez-Faire Thought and the General Welfare State: A Study of Conflict in American Thought, 1865-1901. Ann Arbor: University of Michigan Press.

Fisher, Irving. 1907. Why Has the Doctrine of Laissez Faire Been Abandoned? Science, n.s., 25.627:18-27.

- 1921. Impending Problems of Eugenics. Scientific Monthly 13.3:214-31.

Freeden, Michael. 1979. Eugenics and Progressive Thought: A Study in Ideological Affinity. Historical Journal 22.3:645-71.

Furner, Mary. 1975. Advocacy and Objectivity: A Crisis in the Professionalization of American Social Science, 1865-1905. Lexington: University Press of Kentucky.

Galton, Francis. 1869. Hereditary Genius. London: Macmillan.

. 1883. Inquiries into Human Faculty and Its Development. London: J.M. Dent and Sons.

. 1908. Memoirs of My Life. London: Methuen.

Gould, Stephen Jay. 1981. The Mismeasure of Man. New York: Norton.

Grant, Madison. [1916] 1921. The Passing of the Great Race or, The Racial Basis of European History. 4th ed. New York: C. Scribner's Sons.

Hall, Prescott. 1904. Selection of Immigration. Annals of the American Academy of Political and Social Science 19:169-84.

Haller, Mark H. 1984. Eugenics: Hereditarian Attitudes in American Thought. New Brunswick, N.J.: Rutgers University Press.

Henderson, Charles Richmond. 1900. Science in Philanthropy. Atlantic Monthly 85.508:249-54.

. 1909. Are Modern Industry and City Life Unfavorable to the Family? American Economic Association Quarterly, 3d ser., 10.1:217-32.

Hodgson, Dennis. 1991. Ideological Origins of the Population Association of America. Population and Development Review 17.1:1-34.

Hoffman, Frederick L. 1896. The Race Traits and Tendencies of the American Negro. Publications of the American Economic Association 11.1-3:1-329.

Kellogg, Paul. 1913. Immigration and the Minimum Wage. Annals of the American Academy of Political and Social Science 48 (July): 66-77.

Kevles, Daniel. 1995. In the Name of Eugenics. Cambridge: Harvard University Press.

_ 1999. Eugenics and Human Rights. British Medical Journal 318:435-38.

King, Miriam, and Steven Ruggles. 1990. American Immigration, Fertility, and Race Suicide at the Turn of the Century. Journal of Interdisciplinary History 20.3:34769.

Kuczynski, R. R. 1901. The Fecundity of the Native and Foreign Born Population in Massachusetts. Quarterly Journal of Economics 16.1:1-36.

Leonard, Thomas C. 2000. The Very Idea of Applying Economics: The Modern Minimum-Wage Controversy and Its Antecedents. In Toward a History of Applied Economics, edited by Roger Backhouse and Jeff Biddle. HOPE 32 (supplement): 117-44. 
2003a. "A Certain Rude Honesty": John Bates Clark as a Pioneering Neoclassical Economist. HOPE 35.3:521-58.

. 2003b. American Progressive-Era Political Economy: The Case of Legal Minimum Wages. Unpublished manuscript.

Ludmerer, Kenneth M. 1972. Genetics and American Society. Baltimore: Johns Hopkins Press.

Mayo-Smith, Richmond. 1888a. Control of Immigration I. Political Science Quarterly 3.1:46-77.

ـ 1888b. Control of Immigration II. Political Science Quarterly 3.2:197-225. 1888c. Control of Immigration III. Political Science Quarterly 3.3:409-24.

Meeker, Royal. 1910. Review of Cours d'économie politique. Political Science Quarterly 25.3:543-45.

Menand, Louis. 2001. The Metaphysical Club. New York: Farrar, Straus and Giroux. Miller, Kelly. 1917. Eugenics of the Negro Race. Scientific Monthly 5.1:57-59.

Morton, Samuel G. 1839. Crania Americana. Philadelphia: John Pennington.

Moss, David. 1996. Socializing Security: Progressive-Era Economists and the Origins of American Social Policy. Cambridge: Harvard University Press.

Myrdal, Gunnar (with the assistance of Richard Sterner and Arnold Rose). 1944. An American Dilemma. 2 vols. New York: Harper and Brothers.

Nearing, Scott. 1912. The Super Race: An American Problem. New York: B.W. Huebsch.

Orloff, Ann Shola, and Theda Skocpol. 1984. Why Not Equal Protection? Explaining the Politics of Public Social Spending in Britain, 1900-1911, and the United States, 1880s-1920. American Sociological Review 49.6:726-50.

Patten, Simon N. 1909. The Making of Economic Literature. Annual Address of the President. American Economic Association Quarterly, 3d ser., 10.1:1-14.

_ 1912. Theories of Progress. American Economic Review 2.1:61-68.

Paul, Diane. 1984. Eugenics and the Left. Journal of the History of Ideas 45.4:56790.

2001. History of Eugenics. International Encyclopedia of Social and Behavioral Sciences, edited by Neil Smelser and Paul Baltes. Amsterdam: Elsevier.

Pigou, A. C. 1907. Social Improvement in the Light of Modern Biology. Economic Journal 17.67:358-69.

Ripley, William Z. 1899. The Races of Europe: A Sociological Study. New York: D. Appleton and Co.

Riis, Jacob. [1890] 1997. How the Other Half Lives: Studies among the Tenements of New York. New York: Penguin Books.

Rodgers, Daniel T. 1982. In Search of Progressivism. Reviews in American History 10:113-32.

1998. Atlantic Crossings: Social Politics in a Progressive Age. Cambridge, Mass.: The Belknap Press.

Roosevelt, Theodore. 1907. A Letter from President Roosevelt on Race Suicide. American Monthly Review of Reviews 35.5:550-51. 
Ross, Dorothy. 1991. The Origins of American Social Science. Cambridge: Cambridge University Press.

Ross, Edward Alsworth. 1901a. The Causes of Race Superiority. Annals of the American Academy of Political and Social Science 18.1:67-89.

- 1901b. Social Control: A Survey of the Foundations of Order. New York: Macmillan.

— 1907. Social Darwinism. American Journal of Sociology 12.5:695-716.

- 1936. Seventy Years of It. New York: D. Appleton-Century Company.

Seager, Henry Rogers. 1913a. The Minimum Wage as Part of a Program for Social Reform. Annals of the American Academy of Political and Social Science 48 (July): 3-12.

. 1913b. The Theory of the Minimum Wage. American Labor Legislation Review 3:81-91.

. 1923. Principles of Economics. 3d ed., rev. New York: Henry Holt.

Skocpol, Theda. 1992. Protecting Soldiers and Mothers: The Political Origins of Social Policy in The United States. Cambridge, Mass.: The Belknap Press of Harvard University Press.

Taussig, Frank W. 1921. Principles of Economics. Vol 2. 3d ed., rev. New York: Macmillan.

Tugwell, Rexford. 1923. Notes on the Life and Work of Simon Nelson Patten. Journal of Political Economy 31.2:153-208.

von Thünen, J. H. [1850] 1966. Isolated State: An English edition of Der isolierte Staat. Translated by Carla M. Wartenberg. Oxford: Pergamon Press.

Walker, Francis Amasa. 1891. Immigration and Degradation. Forum (August): 11:634-644.

. 1892. Immigration. Yale Review 1.2:125-45.

. 1896. Restriction of Immigration. Atlantic 77:822-29.

1899. Discussions in Economics and Statistics. Vol 2. Edited by Davis Dewey. New York: Henry Holt and Co.

Ward, Lester. 1913. Eugenics, Euthenics, and Eudemics. American Journal of Sociology 18.6:737-54.

Webb, Sidney. 1910-11. Eugenics and the Poor Law: The Minority Report. Eugenics Review 2:233-41.

- 1912. The Economic Theory of a Legal Minimum Wage. Journal of Political Economy 20.10:973-98.

Webb, Sidney, and Beatrice Webb. [1897] 1920. Industrial Democracy. London: Longmans Green.

Wilcox, Walter. 1914. Differential Fecundity. Journal of Heredity 5:141-48.

Wolfe, A. B. 1917. Some Phases of the Minimum Wage: Discussion. American Economic Review 7.1:275-81.

Young, Allyn A. 1905. The Birth-Rate in New Hampshire. Publications of the American Statistical Association 9.71:263-91. 